\title{
The Phenomenon of Women's Body Mass Index
}

\author{
Mustika Fitri* \\ Fakultas Pendidikan Olahraga dan Kesehatan \\ Universitas Pendidikan Indonesia \\ Bandung, Indonesia \\ *mustikafitri@upi.edu
}

\author{
Jajat Jajat ${ }^{1,2}$ \\ ${ }^{1}$ Physical Education, Health and Recreation, ${ }^{2}$ Fakultas \\ Pendidikan Olahraga dan Kesehatan \\ ${ }^{1}$ Universitas Galuh, ${ }^{2}$ Universitas Pendidikan Indonesia \\ ${ }^{1}$ Ciamis, Indonesia, ${ }^{2}$ Bandung, Indonesia \\ jajat_kurdul@upi.edu
}

\begin{abstract}
The article aims to discuss about Body Mass Index (BMI) of women. The research uses mix method. The data are collected by studying 186 participants. The participants are 99 early women adults and 87 late women adults. All of them join the sport recreation program in different sport clubs in Bandung. They join the program for about one year. The analysis are started by finding the phenomenon of the BMI of participants. The researcher uses formula to measure the participants' body mass index. Then, independent samples of t-test are calculated to determine BMI differences. Finally, it shows that there are significance BMI differences between early women adults and late women adults $(\mathbf{p}<\mathbf{0 . 0 2 3})$. Since it is considered that the participants are categorized: early and late women adults, the result can be revealed in thick and deep phenomenon. It shows that late women adults have more percentage for pre-obesity and obesity level 1 than the early ones. The researcher also find out their reason in joining the sport recreation program. Their healthy living behaviors can be affected by their geographic location.
\end{abstract}

Keywords - body mass index; women, sport recreation program; healthy living behaviour; pre-obesity; obesity level 1

\section{INTRODUCTION}

Women are related to the civilization, culture, and healthiness. If the research do the study to the women related to those themes, it may interpret several parts of citizen in the world. Women have their own parts to develop the civilization in every single aspect, include in healthy living behavior. The healthy living behaviors have strong relationship to the Body Mass Index. It is because BMI can help people to check their percentage of pre-obesity and obesity level 1. As it is believed that obesity is one of factors that causing the death. Thus, this study try to reveal the phenomenon of BMI faced by early and late women adults.

\section{A. Women's Rights in Sports}

Nowadays people believe that women have the human rights. It is called emancipation. Women have their freedom to express their ideas without any limitation from their society [1]. In the part of life aspects, women handle some vital roles, whether it is political, cultural, even in sports. In the past, sports are used to perform masculinity, but nowadays women becoming the part of them [2]. In this era, women no longer shut themselves towards sports activities [3]. They perform their skills and interests in sport confidently. Amazingly, women's contribution in sports can be generalized as equal to men [4], from 1427 adults who participate in sports, there are $54,9 \%$ male participants and $45,1 \%$ female ones. Although they get differences of ability, status, and experience, women have possibilities to achieve equal rights in earning certain statuses in the society, for example: their participation in sports [5]. Thus, sports hopefully can give change to get better future and healthy life style for women.

\section{B. Women's Action on Sport Activities}

Women show their capabilities in sports by achieving their action on sport activities [6]. They deliver their competencies in their skill. There are no doubts on women's consciousness -even late women adults-- to do sport all their lives as a daily need [7]. However, some women do sport activities to achieve the prestige and the social level in their daily lives. They are brave to compete with other. It has been proven that there are a lot of professional competitions for women [8].

\section{C. $B M I$}

BMI is one of the indicators to detect the relative fat content in someone's body, especially for the adult of 20 years old and more. BMI is used to determine someone's weight status, whether they are too thin, ideal, or too fat [9]. BMI helps people to evaluate someone's weight status towards any health risk with the cause of underweight or overweight [10]

\section{Sports, Fat, and Public Area}

For teenagers and adult women, fat has always been a problem. The desire to have the body goal is being interpreted as having a slim body [11]. They really prioritize themselves to look pretty or fit. Then being too thin is not good, therefore also being too fat [12]. With the case of overweight, usually the suggestion is to do diet and do sports. Then, sport place are starting to get crowded by adult women to socialize with fellow member of so [13].

\section{METHOD}

\section{A. Participants}

The participants in this research are 186 women. Those are 99 early women adults and 87 late ones. They are involved in 
the sports and recreations program in Bandung City. Early women are around 26-35 years old. While late women is in the age interval of 36-45 years old. The participants have been involved in sports and recreation activities at least for 1 year in some sports club in Bandung City.

\section{B. Method}

The research uses mix method. It tries to explore the data quantitatively and explain it briefly using the descriptive explanation. The researcher posts the numeric data then describe it. To gain the thick and deep information, the researcher do triangulation data. The researcher do the observation and interview.

\section{Procedure}

Researcher does a survey to some sports club in Bandung to gather some samples that are needed. The researcher does pilot project by gaining the information in the first meeting. Next samples are chosen by age category. They are members of different sports clubs around 1 year and more. Samples are measured for their heights and weights. After that, those are analyzed in the perspective of BMI differences. The last, it is described in descriptive way.

\section{Data Analysis}

To measure body mass index, the formula is

$$
M I=\frac{\text { Body Weight }(\mathrm{Kg})}{\text { Height }(\mathrm{m})^{2}}
$$

After that, it is processed by calculating independent sample t-test. It compares the two sample groups.

\section{RESULT AND DISCUSSION}

The table 1 below indicates that early women adults had an average and deviation standard smaller compared to late women adults.

TABLE I. DESCRIPTIVE STATISTICS

\begin{tabular}{|l|c|c|}
\hline \multicolumn{1}{|c|}{ BMI } & \multicolumn{1}{c|}{ M } & SD \\
\hline Early WA & 22.39 & 3.79 \\
\hline Late WA & 23.67 & 3.82 \\
\hline
\end{tabular}

From 99 participants, 12 early women adults are categorized as thin, 67 women are categorized as normal, 17 women are categorized as pre-obesity, 2 women are categorized as level 1 obesity, and 1 woman is categorized as level 2 obesity. While for late women adults, 6 women are categorized as thin, 51 women are categorized as normal, 22 women are categorized as pre-obesity, and 8 women are categorized as level 1 obesity.

Those phenomenon show that the participants who join the sport recreation program are not in same good physical condition. However, they try to do their best to keep their healthiness. Both of early and late women adult can be detected. Phenomene that the early women adult have smaller number in tabel 1. Then, it is important to find ot the suitable sport program related to the data.

TABLE II. PARTICIPANTS BMI CATEGORY CROSS TABULATION

\begin{tabular}{|c|c|c|c|c|c|c|c|c|}
\hline & \multicolumn{5}{|c|}{ BMI Category } & \multirow[b]{2}{*}{$\begin{array}{c}\text { Tot } \\
\text { al }\end{array}$} \\
\hline & & & $\begin{array}{c}\text { Thi } \\
n\end{array}$ & $\begin{array}{c}\text { No } \\
\text { rm } \\
a l\end{array}$ & $\begin{array}{c}\text { Pre- } \\
\text { Obesi } \\
\text { ty }\end{array}$ & $\begin{array}{c}\text { Obe } \\
\text { sity } \\
1\end{array}$ & $\begin{array}{l}\text { Ob } \\
\text { esit } \\
\text { y } 2\end{array}$ & \\
\hline \multirow{6}{*}{$\begin{array}{l}\text { Part } \\
\text { icip } \\
\text { ants }\end{array}$} & \multirow{3}{*}{$\begin{array}{c}\text { Earl } \\
\text { y } \\
\text { wom } \\
\text { en }\end{array}$} & Count & 12 & 67 & 17 & 2 & 1 & 99 \\
\hline & & $\begin{array}{c}\text { \% within } \\
\text { Participan } \\
\text { ts }\end{array}$ & $\begin{array}{l}12 . \\
1 \%\end{array}$ & $\begin{array}{l}67 . \\
7 \%\end{array}$ & $\begin{array}{l}17.2 \\
\%\end{array}$ & $\begin{array}{l}2.0 \\
\%\end{array}$ & $\begin{array}{l}1.0 \\
\%\end{array}$ & $\begin{array}{l}100 \\
.0 \\
\%\end{array}$ \\
\hline & & \% of Total & $\begin{array}{l}6.5 \\
\%\end{array}$ & $\begin{array}{l}36 . \\
0 \%\end{array}$ & $9.1 \%$ & $\begin{array}{l}1.1 \\
\%\end{array}$ & $\begin{array}{l}0.5 \\
\%\end{array}$ & $\begin{array}{l}53 . \\
2 \%\end{array}$ \\
\hline & \multirow{3}{*}{$\begin{array}{c}\text { Late } \\
\text { wom } \\
\text { en }\end{array}$} & Count & 6 & 51 & 22 & 8 & 0 & 87 \\
\hline & & $\begin{array}{c}\text { \% within } \\
\text { Participan } \\
\text { ts }\end{array}$ & $\begin{array}{l}6.9 \\
\%\end{array}$ & $\begin{array}{l}58 . \\
6 \%\end{array}$ & $\begin{array}{l}25.3 \\
\%\end{array}$ & $\begin{array}{l}9.2 \\
\%\end{array}$ & $\begin{array}{l}0.0 \\
\%\end{array}$ & $\begin{array}{l}100 \\
.0 \\
\%\end{array}$ \\
\hline & & \% of Total & $\begin{array}{l}3.2 \\
\%\end{array}$ & $\begin{array}{l}27 . \\
4 \%\end{array}$ & $\begin{array}{l}11.8 \\
\%\end{array}$ & $\begin{array}{l}4.3 \\
\%\end{array}$ & $\begin{array}{l}0.0 \\
\%\end{array}$ & $\begin{array}{l}46 . \\
8 \%\end{array}$ \\
\hline \multirow{3}{*}{\multicolumn{2}{|c|}{ Total }} & Count & 18 & $\begin{array}{l}11 \\
8\end{array}$ & 39 & 10 & 1 & 186 \\
\hline & & $\begin{array}{c}\text { \% within } \\
\text { Participan } \\
\text { ts }\end{array}$ & $\begin{array}{l}9.7 \\
\%\end{array}$ & $\begin{array}{l}63 . \\
4 \%\end{array}$ & $\begin{array}{l}21.0 \\
\%\end{array}$ & $\begin{array}{l}5.4 \\
\%\end{array}$ & $\begin{array}{l}0.5 \\
\%\end{array}$ & $\begin{array}{l}100 \\
.0 \\
\%\end{array}$ \\
\hline & & $\%$ of Total & $\begin{array}{l}9.7 \\
\%\end{array}$ & $\begin{array}{l}63 . \\
4 \%\end{array}$ & $\begin{array}{l}21.0 \\
\%\end{array}$ & $\begin{array}{l}5.4 \\
\%\end{array}$ & $\begin{array}{l}0.5 \\
\%\end{array}$ & $\begin{array}{l}100 \\
.0 \\
\%\end{array}$ \\
\hline
\end{tabular}

Based on the data processing (independent sample t-test) it is known that recreation sports gave a different effect towards the average BMI for early women adults and late women adults $(p=.000)$. However, all of women show the interest in doing sport.

TABLE III. BMI DIFFERENCES WOMEN ADULTS

\begin{tabular}{|c|l|l|}
\hline $\mathbf{t}$ & $\mathbf{P}$ & Mean difference \\
\hline 5.682 & .000 & 31.02 \\
\hline
\end{tabular}

BMI refers to body far percentage more than $35 \%$ on women are classified as obesity [14]. Based on the result of data processing and analysis, late women adults are categorized as the obesity. It is around $34 \%$. On early women adults, the percentage are only $20 \%$. It means that late women adults are more vulnerable to be obese compared to those who are an early women adult. Obesity is closely related to age [15], even though through physical activity it was relatively same. Obesity prevalence on men and women raise along with aging, and then decline on a certain age interval [16]. Eating pattern is also one of the factor that causes the raise of the weight status [17], besides the involvement in sports or physical activities.

BMI becomes a screening tools that is used to determine the weight problems on adults. Although BMI is not a diagnostic tool for health problem [18]. Due to the limitation of research, deeper identification about the involvement frequency in physical activity towards BMI is needed. 


\section{CONCLUSION}

This research shows that there are body mass index differences between early women adults and late women adults. As seen from the percentage, late women adults had more percentage for pre-obesity and obesity level 1 . It is concluded that BMI help the researcher to know about participants' condition and finding. That women especially in both out early and late condition can check their limitation and try to control their sport activitis.

\section{ACKNOWLEDGMENT}

Fitri and Jajat thanks to Allah who help the researchers. Both of them also thanks to family, relatives, for their support them to finish the paper. Especially to Rasi Yugafiati for her proof reading. Hope God bleesses us.

\section{REFERENCES}

[1] G. Pfister, "Women in sport-gender relations and future perspectives," Sport in Society, vol. 13(2), pp. 234-248, 2010

[2] S.D. Marshall, P. Sanderson, C.A. Mcintosh, and H. Kolawole, "The effect of two cognitive aid designs on team functioning during intra-operative anaphylaxis emergencies: a multi-centre simulation study," Anaesthesia, vol. 71(4), pp. 389-404, 2016

[3] R.O. Deaner, D.C. Geary, D.A. Puts, S.A. Ham, J. Kruger, E. Fles, ... and T. Grandis, "A sex difference in the predisposition for physical competition: males play sports much more than females even in the contemporary US," PloS one, vol. 7(11), pp. e49168, 2012

[4] M. Asztalos, K. Wijndaele, I. De Bourdeaudhuij, R. Philippaerts, L. Matton, N. Duvigneaud, ... and G. Cardon, "Sport participation and stress among women and men," Psychology of Sport and Exercise, vol. 13(4), pp. 466-483, 2012.

[5] R. Eime, J. Young, J. Harvey, and W. Payne, "Psychological and social benefits of sport participation: The development of health through sport conceptual model," Journal of Science and Medicine in Sport, vol. 16, pp. e79-e80, 2013

[6] L. Coleman, L. Cox, and D. Roker, "Girls and young women's participation in physical activity: psychological and social influences," Health education research, vol. 23(4), pp. 633-647, 2007
[7] S. Horton, R.A. Dionigi, M. Gard, J. Baker, and P. Weir, "Don't sit back with the geraniums, get out: The complexity of older women's stories of sport participation," Journal of Amateur Sport, vol. 4(1), pp. 24-51, 2018.

[8] C. Dunn, "Elite footballers as role models: promoting young women's football participation," Soccer \& Society, vol. 17(6), pp. 843-855, 2016.

[9] J.A. Rye, S.L. Rye, I. Tessaro, and J. Coffindaffer, "Perceived barriers to physical activity according to stage of change and body mass index in the West Virginia Wisewoman population,"Women's Health Issues, vol. 19(2), pp. 126-134, 2009.

[10] M.L. Neuhouser, A.K. Aragaki, R.L. Prentice, J.E. Manson, R. Chlebowski, C.L. Carty, ... and R.P. Urrutia, "Overweight, obesity, and postmenopausal invasive breast cancer risk: a secondary analysis of the women's health initiative randomized clinical trials," JAMA oncology, vol. 1(5), pp. 611-621, 2015

[11] C.M. Sabiston, J. Brunet, K.C. Kowalski, P.M. Wilson, D.E. Mack, and P.R. Crocker, "The role of body-related self-conscious emotions in motivating women's physical activity," Journal of Sport and Exercise Psychology, vol. 32(4), pp. 417-437, 2010.

[12] K. Esposito, A. Pontillo, C. Di Palo, G. Giugliano, M. Masella, R. Marfella, and D. Giugliano, "Effect of weight loss and lifestyle changes on vascular inflammatory markers in obese women: a randomized trial," Jama, vol. 289(14), pp. 1799-1804, 2003.

[13] K.P. Derose, B. Han, S. Williamson, and D.A. Cohen, "Gender disparities in park use and physical activity among residents of highpoverty neighborhoods in Los Angeles," Women's Health Issues, vol. 28(1), pp. 6-13, 2018.

[14] A. Romero-Corral, V.K. Somers, J. Sierra-Johnson, R.J. Thomas, M.L Collazo-Clavell, J.E.C Korinek, ... and F. Lopez-Jimenez, "Accuracy of body mass index in diagnosing obesity in the adult general population," International journal of obesity, vol. 32(6), pp. 959, 2008.

[15] S.M. Sidik and L Rampal, "The prevalence and factors associated with obesity among adult women in Selangor, Malaysia," Asia Pacific family medicine, vol. 8(1), pp. 2, 2009.

[16] A. Moody, "Adult anthropometric measures, overweight and obesity," Health survey for England, vol. 1, pp. 1-39.

[17] H.C. Gooding, C.E. Walls, and T.K. Richmond, "Food insecurity and increased BMI in young adult women," Obesity, vol. 20(9), pp. 18961901, 2012.

[18] C.A. Schoenborn and P.E. Adams, "Health behaviors of adults: United States, 2005-2007," Vital Health Stat 10, vol. 245(1), pp. 132, 2010. 